\title{
Yeni Medya ve Dijital Gözetim: Türkiye'deki Sosyal Medya Kullanıcıları Üzerine Bir Araştırma
}

\author{
Sefer KALAMAN**
}

\begin{abstract}
$\ddot{O} Z$
Yeni iletişim teknolojileri ile birlikte insan hayatı bugüne dek hiç olmadığ kadar çok ve

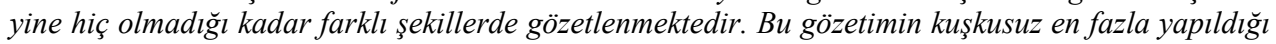
mecra ise yeni medya ve yeni medyanın en önemli ortamı olan sosyal paylaşım ağlarıdır. Bu noktadan hareketle yapılan çalışmada, Türkiye'de yaşayan insanların yeni medyada bilgilerini ne oranda paylaştıklarını ve yeni medya aracılığıyla gözetlendiklerin farkında olup olmadıklarını tespit etmek amaçlanmıştır. Çalışmada verileri elde etmek için bir saha araştırması yapılmış ve araştırmada nicel araştırma yöntemlerinden biri olan anket tekniği kullanılmıştır. Araştırmanın evrenini, Türkiye'de yaşayan 15 yaş ve üzerindeki yaklaşı 35 milyon Facebook kullanıcısı oluşturmaktadır. Örneklemi ise, Türkiye'de yaşayan, 15 yaş ve üzerindeki 5000 Facebook kullanıcısı temsil etmektedir. Çalışmada elde edilen bulgulara göre, katılımcıların Facebook'ta bilgilerini paylaşma düzeyleri yüksek olmaktadır. Bunun yanında katılımcıların Facebook aracılığıyla ticari şirketler ve kamu kurumları tarafindan gözetlendiklerinin farkında olma düzeyleri ise düşük olmaktadır. Çalışmada ayrıca katılımcıların gözetim farkındalıkları, cinsiyet, yaş, eğitim, yaşanılan yer, çalışma durumu ve bölge grupları temelinde incelenmiş ve anlaml farklılıklara ulaşılmışıtır.
\end{abstract}

Anahtar Kelimeler: Yeni Medya, Gözetim, Dijitalleşme, Facebook

JEL Sinıflandırması: Y90, Z00, Z13

\section{New Media and Digital Surveillance: A Study on Social Media Users in Turkey}

\begin{abstract}
Through new communication technologies, human life has been observed numerous and more different ways than ever before. This surveillance is undoubtedly carried out in new media and in social networks which the most important media of the new media. From this point, this study aims to determine both how much the Turkish people share their knowledge in the new media and whether Turkish people are aware that they are being monitored through the new media. A field study was conducted to obtain data and one of the quantitative research methods, the survey technique was used. Nearly 35 million Facebook users aged 15 and over living in Turkey constitute the universe of the research. 5000 Facebook users aged 15 and over living in Turkey represent the sample of research. According to the findings of the study, the level of sharing the information of the participants in Facebook is high. Furthermore, the level of awareness of participants being watched by commercial companies and public institutions through Facebook is low. The surveillance awareness of participants were also analyzed on the basis of gender, age, education, place of residence, working status and region groups, and significant differences were found.
\end{abstract}

Keywords: New Media, Surveillance, Digitalization, Facebook

JEL Classification: Y90, Z00, Z13

\footnotetext{
* Bu çalışma, yazarın Ege Üniversitesi Sosyal Bilimler Enstitüsü Radyo Televizyon ve Sinema Anabilim Dalında hazırlanan "Sosyokültürel, Ekonomik ve Siyasi Boyutlarıyla Yeni Medyada Mahremiyetin Dönüşümü: Facebook Örneği”" adlı doktora tezinden üretilmiştir.

** Dr. Öğr. Üyesi, Yozgat Bozok Üniversitesi, İletişim Fakültesi, sefer.kalaman@bozok.edu.tr
} 


\section{GİRIŞ}

Sosyal ağlar, haber siteleri, forumlar, web tvler ve bloglar gibi farklı dijital/sanal ortamlar sahip olan yeni medya, önceleri iletişim sürecinde pasif konumda bulunan alıcıları, medya içeriğini üretme, yayma ve etkileşim kurma olanaklarına kavuşturarak aktif konuma getirmiştir. Yeni medyanın, en bilinen ve en çok kullanılan platformu olan sosyal paylaşım ağları ise, bireyi sözü geçen iletişime aracısız dahil etmesi ve içerikleri kendilerinin üretmesine imkan sağlaması hasebiyle diğer sanal platformlara göre kullanıcılar tarafindan daha tercih edilmiştir. Bu sanal ağlarda arzuladığ 1 iletişimi ve ilişkiyi oluşturabilme imkanına ulaşan bireyler, bu sanal ortamın çok kısa zamanda devasa sayıda kullanıcıya ulaşmasına önayak olmuştur. Dijitalleşip sosyalleşme arzusu ile hayatının her noktasını bu sanal ortama adapte eden ve kendisine dair ne varsa yine bu ortamda paylaşan birey, bu bilgileri diğer kullanıcıların ve daha önemlisi ticari şirketlerin ve birçok kamu kurumunun önüne serip onların gözetimine sunmuştur.

Bununla birlikte, bireyler, ticari șirketler ve kamu kurumları tarafindan yeni iletişim teknolojileri ve özellikle sosyal paylaşım ağları vasıtasıyla gerçekleştirilen gözetim nedeniyle toplum yapısı da bir dönüşüme uğrayarak, adına dijital gözetim toplumu denilen yeni bir toplum yapısına evrilmiştir. Halihazırda dijital gözetim toplumu olarak adlandırılan bu toplum yapıs1, Panaptikon, Sinoptikon ve Süper Panoptikon gibi birçok evreden geçerek bugünkü haline yani Omniptikon'a ulaşmıştır. Omniptikon ile birlikte gözetim, azların çoğu ya da çokların azı gözetleme durumundan annenin çocuğu, çocuğun anneyi, ünlünün halkı, halkın siyasetçileri, iş yerinde çalışanların patronu, patronun çalışanları, şirketlerin müşterilerini kısacası herkesin herkesi gözetlediği bir yapıya dönüşmüştür.

Omniptikon ortamında gerçekleşen gözetim stratejileri farklı özneler (şirketler, kamu kurumları, sosyal paylaşım ağı kullanıcıları) tarafindan farklı amaçlar için kullanılmaktadır. Şirketler sosyal paylaşım ağlarını ve diğer teknolojik imkanları kullanarak daha fazla gelir elde etmek için gözetim yaparken, kamu kurumları da toplumsal kontrol ve güvenlik için insanları gözetlemektedir. Sosyal paylaşım ağlarını kullanan insanlar ise sosyalleşme, merak, haz, bilgi edinme ve kontrol etme arzusu gibi nedenlerle başka kullanıcıları gözetlemekte ve aynı şekilde gözetlenmektedir.

Haz, merak, sosyalleşme arzusu gibi nedenlerle kimlik bilgilerini, yaşadığı yeri, kişisel fotoğraflarını, videolarını, yediği şeyleri, gittiği yerleri kısacası yaptığı her şeyi ve kendisine ait olan her bilgiyi bu sosyal paylaşım ağlarında paylaşarak daha çok bilmek/görmek ve daha çok bilinmek/görünmek isteyen özneler bu uğurda kendilerini gözetim çarkına sokmakta ve kişisel, özel ve mahrem bilgilerini başka kişi, kurum ve kuruluşların kullanımına sunmaktadır. $\mathrm{Bu}$ ise bireyin sıradan bir veri öznesi olmasına neden olmakta ve bireyin birçok açıdan hayatının ihlal edilmesine yol açmaktadır. 


\section{GÖZETIM KAVRAMI VE TARİHSEL SÜREÇTE GÖZETIMIIN EVRELERI}

Gözetim, insanoğlunun var olduğu andan itibaren denetim unsuru olarak her daim gerçekleşmiştir. İnsanlar, kendilerine hükmedenler tarafından çeşitli amaçlarla ve çeşitli şekillerde gözetlenmişlerdir. Fakat modern dönemde, gözetimin pratiği de dönüşüme uğramıştır. Dar anlamda bireyi genel çerçevede de toplumu gözetim altına alma işi çok daha geniş boyutta ve elektronik bir şekle evrilmiştir. Elektronik araçlar ve teknolojik imkanlar dahilinde gerçekleştirilen gözetim artık neredeyse bütün insanları gözetleyecek ve takip edecek düzeye ulaşmıştır.

Temelde görme ve izleme eylemlerini içeren fakat bu eylemler gerçekleştirilirken farklı araçlar kullanılarak yapılan gözetim, iki açıdan ele alınmaktadır. Birincisi, gözetim insanların davranış biçimlerini kontrol etmek için kullanılan ve onlar hakkındaki bilginin toplanıp şifrelenip kodlandığ uygulama iken, ikincisi, insanların davranışlarının, onlar üzerinde baskı oluşturan ya da otoritesini kullanan diğer insanlar tarafından direkt izlenmesini içermektedir (Giddens, 2008: 24). Bununla birlikte ilk gözetim, biriktirme ya da depolama yoluyla yapılan gözetim, ikincisini de izleme yoluyla yapılan gözetim olarak adlandırmaktadır. (Karakehya, 2009: 325).

Geniş perspektiften bakıldığında gözetim, sosyal kontrolün önemli bir aracı olmaktadır. Aileler çocuklarını, öğretmenler öğrencilerini, işverenler çalışanlarını, dini liderler cemaatinde gerçekleşen eylemleri, polis sokakları ve diğer kamusal alanları ve devlet de yasalarla belirlenmiş yasak ve yükümlülüklere uyup uymadıklarını tespit etmek için halkını izlemektedir (Westin, 1967: 57). Bunun haricinde gözetim, belli insan davranışlarının dikkate alındığı süreçlere de işaret etmektedir. Güvenliklerinden kaygılanıldığ 1 için birilerinin başkalarını izlemesi, cankurtaranın havuza/denize girenleri takip etmesi ya da polisin otoparkta şüpheli faaliyetlerde bulunan birini izlemesi bu tür gözetime örnek oluşturmaktadır. Ayrıca soykırım şüphesi barındıran toplu mezarların aranmasında uydu görüntülerinden yararlanılması yahut kuş gribinin nasıl yayıldığının ortaya çıkarılması için kuşların halkalanması da gözetimin farklı boyutlarını gösteren misaller olmaktadır (Lyon, 2013: 30-32). Lakin gözetimi, sadece sosyal yaşamın devamını sağlamak, olası tehlikeleri önlemek ya da meydana gelen olumsuz vakaları düzeltmek için kullanılan bir araç/sistem olarak görmek, gözetimi ve onun mahiyetini anlama noktasında yetersiz kalınması sonucunu doğuracaktır. Bahsedilen bu amaçlardan ziyade çalışmada gözetim, Bauman ve Lyon'un (2013: 8) tanımladığı gibi, "sistemli şekilde izleme, kontrol altına alma, takip etme ve gözetleme" ya da Giddens'in dediği gibi, "bireylerin/toplumun davranışlarının, bunlar üzerinde otorite kuran siyasi erkler, çıkar amaçlı şirketler ve fişleme amaciyla izleme yapan kamu kurumları tarafından doğrudan izlenilmesi” şeklinde ele alınmaktadır.

Gözetim olgusu pek çok yazar tarafından farklı değerlendirmeler baz alınarak farklı şekilde sınıflandırılmıştır. Gözetim çalışmaları üzerine derin araştırmaları bulunan David Lyon (2013: 113-114) gözetim tekniklerini üç 
döneme ayırmaktadır; bunlar modern öncesi, modern ve postmodern dönemlerdeki gözetim teknikleridir. Lyon haricinde gözetim alanındaki birçok araştırmacı farklı sınıflandırmalar yapmış ancak temelde gözetimin dönemlere ayrılmasının teknolojinin gelişimi ile bağlantılı olduğu sonucuna varılmıştır. Teknolojik imkanlar geliştikçe zaman içinde gözetimin mahiyetinde de farklılıklar ve dahi çeşitlilikler medyana gelmiştir. Bu nedenle gözetim, aşamalara ayrılırken internetin doğuşu ve yaygınlaşması orta nokta olarak belirlenmiş ve internettin yaygınlaşıp geniş kitlelerce kullanılmasından önce "geleneksel dönem, modern dönem" ve internettin yaşamın vazgeçilmez bir aracı halini almasından sonra "postmodern dönem, dijimodern dönem" olmak üzere, özelde dört, temelde ise iki döneme ayrılarak ele alınmıştır.

\section{A. Geleneksel ve Modern Dönemde Gözetim}

Gözetim kavramı yalnızca yaşadığımız bu çağa ait bir unsur olmamaktadır. İnsanlar binlerce yıl zarfında, kaydettikleri ilerlemeyi görme, birbirlerini ve yaptıkları eylemleri kontrol etme dahası örgütlenme, örgütleme, koruma ve korunma hedefiyle diğer insanlara bakıp onları gözetlemiş olmaktadır. Antik çağda yönetici konumunda bulunanlar, Mısır'daki gibi göç, askerlik hizmeti ve vergi gibi nedenlerle nüfusu kayıt etmişler ve kontrol altına almışlardır. Göçebe yaşayan İsrail halkında dahi tarihte birçok kez nüfus sayımı yapılmıştır. Fakat söz konusu dönemde gözetim faaliyetleri kısıtlı bir yapıya sahip olmaktadır. Bunun haricinde etkin, düzenli ve tüm halkı kapsayan bir gözetim faaliyetinden bahsetmek mümkün değildir (Ak, 2013: 382-383). Çünkü teknolojik imkanların olmaması, araç olarak sadece insan gözünün kullanılması ve yöneticilerin yönetmek için gözetimin elzem olduğu fikrine henüz kapılmamış olmaları hasebiyle söz konusu dönemde gözetim tüm toplumu kapsayan bir yapıya sahip olmamaktadır.

Etkin şekilde uygulanan gözetimden bahsetmek için 19. yüzyılın sonları ve 20. yüzyılın başlarına kadar gitmek gerekmektedir. Teknolojinin hızlı gelişim gösterdiği bu yıllara paralel olarak gözetim de hız kazanmıştır. Bireyin bireyi gözetlemesinden ziyade devletin halkını ya da diğer devletleri gözetlemesi esas alındığında, bu dönemde devletin uyguladığı gözetim yöntemlerinin eski zamanlara nazaran çok daha kapsayıcı ve etkin bir yapıya sahip olduğunu söylemek mümkün olmaktadır.

Merkezi bir yapıya sahip, etkin, yaygın ve teknik şekilde gerçekleştirilen gözetim on dokuzuncu yüzyıla kadar gerçekleşmemiştir. Ancak bu yüzyılla beraber gözetimin yayılması ve gerçekleştirilmesi bir o kadar hızlı ve etkin olmuştur. Ülkelerin kendisinin ve halkının güvenliğini sağlama isteği, diğer ülkeleri kontrol etme ve olası savaşta üstün olma arzusu, ticari amaçlar, askerlerin örgütlenmesi, nüfusun kontrol altına alınması gibi nedenlerle gözetim bu dönemden sonra varlık göstermiştir (Dolgun, 2008: 74-75). Söz konusu modern öncesi dönemde, iktidara sahip olanlar kendisine tehdit oluşturacağını düşündüğg̈ kişi ya da kişileri fişlemek için farklı yöntemler kullanmıştır. Gözetim ise bu amaca ulaşmak için kullanılan en etkin ve en yaygın yöntem olmuştur. 
Gözetim amacıyla kullanılan bu yöntemlerin belki de en ilginci ve o dönemin şartlarına göre en etkin olanlarından biri, takip edilen kişinin ellerine, ayakkabısına, giysisine, saçına veya şemsiyesine floresan toz/boya bulaştırılmak ya da kişinin sabununa, tıraş losyonuna veya şampuanına bu tozu/boyayı eklemek suretiyle o kişinin işaretlenmesi olmaktadır. $\mathrm{Bu}$ toz/boya normal 1 şıkta görünmemekte yalnızca ultraviyole 1şık altında fark edilebilmektedir. $\mathrm{Bu}$ yöntem sayesinde tehdit unsuru olarak görülen kişi bu madde sayesinde fişlenmekte ve fişlendiğinin farkına dahi varmadan günlük hayatına devam etmektedir. Diğer bir yöntem ise, yer belirleme cihazları ile kişinin takip edilmesi olmaktadır. Kişinin giysisine, arabasına, çantasına ya da yanında bulundurduğu diğer araçlardan birine küçük radyo sinyali vericisini gizleyerek gözetlenecek kişinin yakın mesafelerden takip edilmesi mümkün kılınmıştır. Bu yönteme yakın bir mahiyete olan fakat uygulanış açısından çok farklı bir yapıya sahip olan yöntem de, yaklaşık 5 metre ile 18 metre arasında etkili takip yapma imkanı veren hap şeklindeki çok küçük bir radyo vericisinin takip edilecek kişinin yutmasını ve böylece vericinin kişinin midesine yerleşmesini sağlayarak şahsin izlenmesi/takip edilmesi olmaktadir (Westin, 1967: 69-70).

Modern dönemde uygulanmaya başlanan ve günümüzde de hala varlığını sürdüren gözetleme/takip etme yöntemlerinden birisi de kişinin telefonlarının ya da ortamın dinlemesi olmaktadır. Özellikle ikinci dünya savaşıyla birlikte ivme kazanan soğuk savaş yıllarında ise doruğa ulaşan telefon dinleme, devlet bünyesindeki istihbarat teşkilatlarının gözetleme işinde en çok başvurduğu yöntem olmuştur. Zaman içinde gelişen teknolojik imkanlar, bireyin ve toplumun farkı şekillerde ve daha kapsamlı şekilde gözetlenmesine de imkan tanımıştır. Gözetlemeye imkan tanıyan bu araçların modern dönemde en etkilisi kuşkusuz güvenlik kameraları olmuştur. Önceleri trafikteki ihlalleri ve kazaları önlemek ve kayıt altına almak için kullanılmaya başlanan güvenlik kameraları zamanla daha kapsamlı bir yapıya bürünerek kamuya açık alanda suçları önleme ve suça karışan kişileri yakalamak için kullanılmıştır.

Tüm bu gözetim faaliyetleri zaman içinde evrilerek bütünleşik sistemler halinde varlığını sürdürmeye devam etmektedir. Yeni teknolojiler, yeni gözetim araçlarını yaratmakta ya da var olan gözetim araçlarını daha kapsamlı hale getirmekte bu sayede de kitlesel gözetim bir öncekine nazaran daha kolay yapilabilmektedir.

\section{B. Postmodern ve Dijimodern Dönemde Gözetim}

Hem modern dönem öncesi ve modern dönemde hem de post modern ve dijimodern dönemde gerçekleşen gözetim ve bu gözetimin yapısı aslında uzun zaman dilimleri sonucunda şekillenmiştir. Fakat geleneksel dönem dediğimiz modern dönemden önceki dönemde gerçekleşen gözetime nazaran postmodern ve dijimodern dönemde gerçekleşen gözetim çok daha kapsayııı ve sahip olunan teknik imkanlar aracılığıyla çok daha kolay uygulanır nitelikte olmaktadır.

Bilhassa 80'li y1llar, var olan teknik imkanlar ve teknolojik gelişmeler paralelinde gözetim amacıyla bilgisayarların kullanıldığı ve tüketici profilleri çıkararak insanların tüketim alışkanlıklarının belirlendiği bir dönem olmuştur. 
Bununla birlikte gözetim eyleminin hedefleri genişlemiş, amaçları değişmiş ve kapsamı artmıştır. Dahası uluslararası şirketler, dünyadaki potansiyeli en fazla olan ülkelerin ve buradaki insanların tüketim alışkanlıklarını belirlemek için söz konusu bu gözetim uygulamalarına daha fazla ilgi duymaktadır (Güven, 2011: 177). Çok hızlı bir biçimde gelişip ve yine çok hızlı bir biçimde yayılmaya devam eden bu küresel gözetimle, insanların hemen hemen her zaman ve her yerde kişisel bilgilerinin oluşturulması, depolanması ve saklanması mümkün olmuştur. Kredi kartını kullandığımız anda, yapılan harcamanın miktarı, sıklığı ve ne olduğu dev veri tabanına işlenmekte ve saklanmaktadır. Sağlık hizmeti alınca oluşturulan hastalık bilgileri, otoban gişesinden geçerken verilen bilgiler, yurt dışına çıkarken alınan ya da verilen eşyalar, parmak izleri ve daha bir çok rutin hayat unsurları gözetime ve depolanmaya maruz kalmaktadır. Ayrıca faturalar ödenecek olunsa, resmi makamlarla bağlantıya geçilmek istense veya çevrimiçi olunsa kişilerin hareketlerinden ve durumundan elde edilen fotoğraf her zamankinden daha görünür ve daha net olmaktadır. Fiziki vücutlar gitgide çoğalan dijital bir veri vücuduna dönüşmektedir (Stalder, 2002: 120).

Kitlesel gözetim her geçen gün daha hızlı, daha kapsayıcı ve daha ucuz yapılmaktadır. Bugün artık birkaç milyon dolara az gelişmiş ya da gelişmekte olan bir ülkenin daha doğru tabirle orta büyüklükteki bir ülkenin kişisel verilerini elde etmek ve arşivlemek mümkün hale gelmiştir (Assange ve diğ., 2013: 48). Öyle ki, 2011 Ağustos'unda Fransız Şirketi Amesys Libya'da Kaddafi'ye; İngiliz Gamma şirketi Ekim 2011'de Mısır güvenlik kurumlarına; İtalyan Hacking Team Şirketi Ekim 2011'de Kuzey Afrika ve Orta Doğu'daki güvenlik şirketlerine DPI yani derin veri analizi gözetim programları satmıştır. Bu durum Avrupa'da birçok tartışmaya neden olmuş, özellikle az gelişmiş ülkelerin halkları üzerine baskı oluşturulacağ1 düşünülerek Avrupa ülkelerinin bunları satması tepkiyle karşılanmıştır. Bu nedenle Avrupa Parlamentosu 27 Ekim 2011'de 567 oyla enformasyon teknolojileri için gözetlemeye ve dinlemeye yarayan iletişim sistemlerinin demokratik ilkelere, insan haklarına ve konuşma özgürlügüne zarar verecek şekilde kullanılması amacıyla satılmasına yasaklamalar getirmiştir (Fuchs, 2012: 3).

Postmodern ve dijimodern dönemde doruk noktasına ulaşan bu gözetim pratikleri bireye kaçacak, saklanacak ve yalnız kalabilecek bir alanı imkânsız k1lmıştır. Büyük çoğunluğu internet tabanlı işleyen bu gözetim teknolojileri birçok şekilde günlük hayatın işleyişi ile bütünleştirilmiştir. Güvenlik, eğlence, hızlı alışveriş, sanal sosyalleşme, hızlı iletişim gibi getirileri olan yeni iletişim (gözetim) teknolojileri karşılığında sistem, kayıtsız şartsız bütün bilgilerimizi onun gözetimine sunmamızı istemekte ve bunu şuan itibariyle başarmış görünmektedir.

\section{GÖZETIM TOPLUMU}

Kişisel yaşamın ayrıntılarını gözetleme konusunda iletişim teknolojilerinin bünyesinde barındırdığı müthiş potansiyelin anlaşılması sonrasında, gözetim toplumu kavramını Marx 1985 yılındaki makalesi ile ilk kullanan kişi olmuştur. Enformasyon teknolojileri sayesinde total özellikteki 
toplumsal denetimin önündeki son engellerden birinin daha yıkıldığını belirtmek için kullanılan bu terimi (Dolgun, 2008: 26-27), daha sonra David Flaherty, Lyon ve Giddens kitap ve makalelerinde gözetim toplumu adıyla ayrıntılı şekilde incelemiştir.

David Lyon, insanların 'vatandaş' kavramı haricinde daha çok 'veri' şeklinde tanımlanmaya başladığı vurgusundan hareketle; gözetim toplumunu, özel hayata dair bütün detayların devamlı olarak sayısız şirket ve devlet organları tarafindan elde edilmesi, depolanması ve işlenmesi şekilde tanımlamaktadır (Dolgun, 2008: 28). Bireyler günün doğumundan günün batmasına kadar her yerde elektronik sistemler, bilgisayarlar ve kameralar ile göz hapsinde tutulmaktadır. Gerçekleştirilen bu gözetim doğrudan yani yüz yüze ya da teknoloji dolayımlı olarak yapılabilmektedir. Ancak günümüz dünyasında ikinci türün hızla gelişmekte olduğunu söylemek mümkündür (Lyon, 2013: 11-12). Artık eski usul takip, fişleme ve gözetlemeyle elde edilen yazılı bilgilerden oluşan dosyaların yerine atılan her adımın, gidilen her yerin, girilen her sitenin, paylaşılan her iletinin yer aldığı aklın havsalanın almayacağı büyüklükteki veri dijital ortamda görülüp yine bu ortamda saklanmaktadır. Genelde toplumu özelde ise bireyi dönüştüren bu gözetim uygulamaları son yüzyıl içerisinde farklı şekillerde gerçekleştirilmiş ve gözetim üzerine çalışan araştırmacılar tarafından farklı isimlerle ifade edilmiştir. Bu gözetim uygulamalarının en bilinenleri Panoptikon, Sinoptikon, Süper Panoptikon ve Omniptikondur.

Yunancaya dayanan yeni bir kelime olan Panoptikon "göz önündeki yer" anlamına gelmektedir. Denetime, hapishanedeki mahkûmların "görünmeyen gözler tarafından gözetlenmesi” biçiminde yeni bir anlam kazandıran bu kavram, denetleyen kişi ya da otoritenin görünmezliği ilkesini de yetkin bir biçimde özetlemektedir (Köse, 2011: 202-203). Panoptikonda arzulanan durum, olabildiğince fazla nedenle gözetim altında olan kişinin her daim gözetlendiğ kanısında olması yahut gözetlenip gözetlenmediğinden tam olarak emin olamaması dolayısıyla hep gözetlendiğini düşünmesidir (Bentham, 2008: 13). Gözetleyenler tarafından yemek yerken, dinlenirken, uyurken kısacası her ne yapıyorsa yaparken izlenip izlenmediğini anlayamayan yahut bilemeyen kişi her an müdahaleye ya da gözetime maruz kalacakmış gibi kendisine otokontrol uygulamaktadır (Bauman, 2012: 39-40).

Foucault'ya göre Panoptikon, aslı itibariyle bir binayı ya da yapıyı temsil etmekten ziyade, bir denetim mekanizmasına işaret etmektedir (Dolgun, 2008: 105). Foucault, Bantham tarafindan ortaya konulan hapishane prototipinden hareketle bakmaya ve görmeye imkân tanıyan uygulamaların nasıl kontrol mekanizmasına dönüştürüldüğünü açıklamaya çabalamıştır. Metaforik şekilde ele aldığı Panoptikon'u modernist gözetim uygulamasına dönüştüren Foucault'ya göre, iktidar sahipleri göz aracılığıyla insanları ve onların fiziksel bedenlerini denetim altına almakta ve disipline tabi kılmaktadır (Tümurtürkan, 2010: 8). Foucault'ya (1992: 254) göre, aslında Panoptikon çeşitli amaçlardan yola çıkarak, benzer iktidar etkilerini yaratan bir makinadır. 
Dönemi itibariyle toplum ve gözetim stratejisi noktasında önemli bir kavram, uygulama ya da bir sistem olan panoptikon, doğduğu ve içinde bulunduğu dönemden sonraki zamanın gözetim stratejilerini kapsar nitelikte olmamaktadır. Öyle ki, gelişen teknoloji, kitlesel gözetimin de farklı şekillerde yapılmasına imkân tanımıştır. Bunun yanında değişen teknoloji, değişen toplum yapısı ve değişen ekonomik yapı nedeniyle gözetimin şekli de panoptik yapıdan farklılaşarak gözetleyen-gözetlenen durumunu azınlıkların elinden alıp çoğunluklara bırakmıştır. Yani azınlıkların çoğunluğu gözetlediği gözetim süreci çoğunlukların azınlığı gözetlediği gözetim sürecine evrilmiştir.

Sinoptikon, çokların azı izlemesi, kendilerini azlara göre adapte etmesi, disipline etmesi anlamına gelmektedir. Bu sistemde, çoklar, azların etkisiyle, düzene ve söylenene uyma davranış1 göstermektedir. Sinoptikon, her ortamdan daha fazla iletişim araçları vasıtasıyla günlük hayatların tasarlanması idealize edilmesi ve bir disiplin ortamını ifade etmektedir. Televizyon ve radyonun neredeyse bütün insanların evlerinde yer almasıyla, çoklar, az olanları (sanatçılar, parti liderleri, devlet büyükleri vb.) izlemeye böylece azları benimsemeye başlamıştır (Saykozof, 2014).

$\mathrm{Bu}$ durum artık gözetimin dijitalleştiğini ve Foucault'nun Panoptikon'unda olduğu gibi fiziki bir gözetleme, hapis altında tutma ve fiziksel ve psikolojik baskıyı hapis altındakilere uygulama yerine komünikasyon ve enformasyon teknolojileri başta olmak üzere gelişen teknolojik imkânlarla insanlara özgür oldukları hissini yaşayacakları sanal bir hapishane oluşturma şeklinde ifade edilebilmektedir. Gözetlendiklerinin farkında olmayan birey bu simülasyonda kendine dair ne varsa, çarkın dişlilerine uyarak onu gözetleyenlerin ellerine kendi istekleriyle vermektedir.

Mark Poster'in Panoptikon'un dijital alana taşınan bir versiyonu şeklinde ortaya attığ kavram olan "Süper-Panoptikon"da ise, insan bedenlerinin, şebeke, veritaban1, enformasyon koridoru gibi yöntemlerle sistemin içine sokulduğu iddia edilmektedir. Dijital alanda gerçekleştirilen günlük eylemler neticesinde bireyin bilgileri dijital alana depolanmakta ve böylece bedenlerimizden ziyade sanal varlığımız görünmez duvarlarla kontrol altına alınmaktadır. Süper-Panoptikon ile Panoptikon arasındaki en önemli ve en büyük fark, insanların bu sürece gönüllü dâhil olmasıdır (Bauman, 2012: 55). Deleuze'ün çalışması da aynı minvalde olmaktadır. Özneyi sabit bir mekânda disipline etmek yerine artık yeni 'denetim' olanakları ve çeşitlilikleriyle, gözetimin gündelik hayatın akışı boyunca tasarlandığını ve dağıtıldığını söylemek mümkün olmaktadır (Lyon, 2013: 95). Günlük rutin hayatın içerisinde gözetlendiğinin farkında olmayıp özgür olduğunu düşünen birey, kimlik bilgilerini, parmak izini, ev adresini, telefon numarasını, ilişkisini ve kendine ait daha birçok bilgiyi gönül rahatlığıla veri deposuna yüklemektedir.

Panoptikon yapısında az olan bireyler çok olanları, Sinoptikondaysa çok olanlar az olanları gözetlerken internet teknolojisi ile birlikte oluşan Omniptikon'da herkes herkesi gözetlemekte ve takip etmektedir. Omniptikon kavramını ilk defa Jeffrey Rosen (2004) "Çıplak Kalabalık" adlı eserinde 
kullanmıştır. Rosen, Omniptikonu internet ile birlikte toplumsal gözetim ekseninde ele almıştır. Özellikle dijimodern dönemde internet, insanların her zamankinden çok daha fazla gözetim altına alınmasına olanak sağlamıştır. Artık internet sayesinde mekân ve zaman mevhumları ortadan kalkmıştır. Herkes herkesi istediği zamanda ve mekânda izleyebilme imkânına kavuşmuştur. Patron işçisini, işçi diğer işçileri, anne bakıcıyı ve çocuğunu, iktidar halkı, halk iktidara mensup kişileri, ünlüler ünlü olmayanları ve ünlü olmayanlar ise ünlü olanları, arkadaş arkadaşı, Afrika kıtasında yaşan biri Avrupalıyı, siyasetçi seçmeni, seçmen ise siyasileri kısacası herkes herkesi çağın medyası olan internet aracıllı̆ğyla evinden, işyerinden hatta yolda yürürken dahi izleyebilmektedir.

Modern ya da postmodern dönemden ziyade dijimodern dönemde gözetimin ulaşmış olduğu sınırları tahayyül etmek dahi imkansız görünmektedir. Bugün artık kişisel veriler hakkında Bentham'ın denetleyicisinin hayal dahi edemeyeceği kadar çok şey bilinmektedir (Lyon, 2013: 257). İnsanların kişisel bilgilerinin, alışveriş alışkanlıklarının, gittiği yerlerin yani her şeyin internet vasıtasıyla kaydedildiği çağda insanlar nasıl, ne zaman ve ne düzeyde izlendiğinin farkında ve bilincinde olamamaktadır. Bu nedenle var olan durumu kanıksayan birey kendine dair ne varsa bu ağlara yüklemekte ve gözetimi kabul etmektedir.

\section{GÖZETIMIN İKİ YÜZÜ VE YENİ MEDYADA GÖZETIM PRATIKLLERI}

İktidar sahipleri toplum hayatında meydana gelen sosyal sorunları öne sürerek toplumu gözetlemeyi meşru kılmaktadır. Suçun önlenmesi, güvenliğin tahsis edilmesi, suçlunun fişlenmesi vb. uygulamaları gerçekleştirme adına kitlesel çapta bir gözetim uygulamasına gidilmektedir.

Özellikle 21. yüzyılda gözetleme sistemleri şirketler ve devlet organları tarafindan yaygın olarak kullanılmaktadır. Bu sistemler temelde iki amaç uğruna gerçekleştirilmektedir: güvenlik ve verimlilik. Ticari şirketler, kendi çalışanlarını gözetlemek suretiyle iş yerindeki verimliliği arttırmayı hedeflemekte, kitleleri gözetleyerek de maddi kazanç elde etmeyi arzulamaktadır. Kamu kurumları yani devlet tarafından gerçekleştirilen gözetim sistemlerinin ise iki yönü vardır; suçu engelleme ve toplumsal kontrol. Yani bir yandan hırsızlık, soygun, kaçakçılık, vb. suçlara karşı korunma sağlamayı amaçlarken, bir yandan da istihbarat kurumlarının belirli toplumsal gruplar veya bireyler üzerinde denetim ve kontrol kurmalarını sağlamaktadır (Özarslan, 2008: 142).

Hem kamu kurumları hem de özel şirketler, tüketiciye ve vatandaşa ait verileri toplamak ve işlemek için gelişen teknik imkânlardan yararlanmaktadır. Onlar, güvenlik ihlallerini, dolandırıcılığ 1 , diğer suçları ve terör faaliyetlerini tespit etmek ve önlemek gayesini öne sürerek halkın davranışları ve tüketici tercihleri hakkında bilgi edinmek ve profil oluşturmak için bu büyük miktardaki verileri kullanmaktadır (Dinev vd., 2008: 214). Bu noktada bireyin kişisel bilgileri ve devletin yarar1/güvenliği çatışıyor gibi görünmektedir. Fakat asıl olan şey bireyin gözetlenmesi değil, gücü elinde bulunduranların maddi çıkar yahut siyasi güç elde etmek için bireyi gözetleyerek bilgilerini depolaması ve bunları kullanmasıdır. Bir taraftan gözetimin gerekliliği bir tarafta da gözetlenmenin 
doğurduğu kayıplar insanları bir çıkmaza sürükler nitelikte olmaktadır. İnsan hayatını kolaylaştırmak, bilimin gelişmesine katkıda bulunmak, sosyal aktiviteleri yerine getirmek ya da güvenliği temin etmek amaçlarıla kullanılan gözetim insana ve topluma fayda getirirken kişisel bilgilerin insanların rızası ve haberi olmadan ele geçirilmesi, insanların kategorize edilmesi, sürekli gözetim altında tutulması ve deyim yerindeyse parmaklıkları olmayan bir hapishanede mahkum edilmesi amaciyla kullanılan gözetim ise özelde bireyin genelde ise toplumun zararına olan bir durum olmaktadır. Toplumun yararına olmayan ve büyük oranda yeni iletişim teknolojileri ve yeni medya aracıllğıyla gerçekleştirilen bu gözetim ise temel olarak iki amaca hizmet etmektedir: Toplumsal kontrol ve tüketim.

Toplumsal kontrol ve güvenlik noktasından bakıldığında, özellikle 11 Eylül ve Bali, Madrid, Londra ve Amman saldırılarından bu yana tüm dünyada pek çok ülkede alınan çeşitli terörizm karşıtı tedbirler arasında bu yeni gözetim teknolojileri de yerini almıştır. Günümüzde iktidarı elinde bulunduranlar görünmez bir şekle bürünmüş olmaktadır. Mimari yapı artık elektronik mimariyle yer değiştirmiştir. Denetleyici göz görünmez olduğu gibi kontrol ettiği alanı da oldukça fazla genişletmiştir (Köse, 2011: 10-11). Sokaklardaki kameralar, cep telefonlarından yayılan sinyaller, bilgisayarların ip numaraları, e-postaların takip edildiği sistemeler vb. vasitasıyla tüm insanlık gözetlenmektedir (Toprak vd., 2009: 146-147). Ayrıca şu an gerçekleştirilen gözetim, soğuk savaş yıllarında istihbarat faaliyetlerinde bulunmak için gerçekleştirilen gözetim kadar da maliyetli yahut karmaşı olmamaktadır.

Öyle ki cep telefonlarının dinlenmesi sanıldığı kadar zor ya da maliyetli değildir. "IMSI Catcher" adlı sistem, cep telefonlarının şifreli verilerini aldatarak, kendini cep telefonu sisteminin röle istasyonu gibi göstermekte bu sayede havadaki şifreli frekanslar yakalanarak konuşmalar kolayca dinlenebilmektedir. Ayrica cep telefonu mikrofonu uzaktan devreye sokularak -telli telefonlarda olduğu gibi verici haline getirilerek- çevredeki konuşmalar dinlenebilmekte ve konuşanın bulunduğu yer milimetrik olarak saptanabilmektedir. Cep telefonunu verici olarak kullanarak dinleme yapmak için, cep telefonunun açık olmasına dahi gerek olmamaktadır. 'Pasif dinleme' olarak adlandırılan yöntemle, -telefonun pili çıkarılmadığı sürece- kapalı cep telefonları da verici görevi görebilmektedir (Dolgun, 2005a: 42). Bunun haricinde FBI'1n 'Karnivor' sistemi de milyonlarca e-posta iletişimini kontrol etmek için 'dinleyicilerden' yararlanırken, uluslararası istihbarat toplama sistemi olan 'Echelon', diplomatik görüşmeler, organize suçlar, terörizm ve siyasi tehdit oluşturduğuna inanılan muhalif grupları denetlemede çok daha güçlü çevrimiçi araçlar kullanmaktadır (Lyon, 2013: 69). Bu tip teknik dinlemelerin ve gözetlemelerin haricinde çağın en popüler iletişim aracı olan sosyal medyada da kişiler takip edilmekte, fişlenmekte, sınıflandırılmakta kısaca gözetim altında tutulmaktadır. Kamu kurumlarının istemesi durumunda ülkedeki bütün vatandaşların sosyal paylaşım ağlarındaki verilerini elde etmek mümkün olmaktadır.

Gerçekleştirilen kitlesel gözetimin bir yönü, toplumsal kontrolü sağlamak ya da diğer bir değişle toplumu daha iyi yönetebilmeyi/denetim altına alabilmeyi 
sağlamak iken diğer yönü de kuşkusuz maddi gelir elde etmektir. İktidara sahip olanlar toplumu kontrol etmek ve siyasi güç kazanmak adına söz konusu kitlesel gözetimi gerçekleştirirken ticari şirketler ise esas olarak daha fazla maddi kazanç elde etmek amaciyla kitleleri gözetleme eylemini gerçekleştirmektedir. Öyle ki modern dönemde, teknolojik gelişmeler ve üretim araçlarındaki artışla beraber artık üretimden ziyade nasıl daha fazla tüketim yapılabileceğinin çözümü önem kazanmıştır.

İnternette tüketicilerin izlemesi, profillerinin çıkarılması ve kullanıcıların tüketim alışkanlıklarının tespit edilmesi sayısal işaretleyiciler vasıtasıyla gerçekleştirilmektedir. Kullanıcıların bilgilerini, web böcekleri, flash çerezleri ve web çerezleri gibi yöntemlerle toplamak en fazla kullanılan yöntemlerdir (Toktaş ve diğ., 2012: 56-58). Bu ve bu gibi ortamlarda paylaşılan bilgiler sınırları tahmin dahi edilemeyecek noktalara ulaşmaktadır. Bir sosyal ağa üye olunurken kabul edilen sözleşmeler ile bireye ait bütün bilgilerin, sayfada yer alan görsel ve yazılı içeriklerin, tüketici alışkanlıklarının tespit edilmesi ve kişiye özel reklamlar sunulması gibi nedenlerle o sosyal ağ sağlayıcısının uygun gördüğü tüm firmalara vermesine de izin veriyor olunmaktadır (Erdal, 2013: 65).

Söz konusu ticari yazılımlarla ya da diğer yöntemlerle kamu kurumlarının ve ticari şirketlerin gerçekleştirmiş olduğu kitlesel gözetimin asıl amacı toplumu kontrol etmek, tüketimi arttırmak ve maddi kazanç elde etmektir. Kitlesel gözetimin toplumu denetim altına alıp sorun daha doğrusu kendisine tehlike oluşturacak birey ya da toplulukları yönlendirme, söndürme ya da yok etme amac1 temel amaç gibi görünse de ticari anlamda maddi kazanç elde etmek de en az toplumsal kontrol kadar önemli bir amaçtır.

\section{ARAŞTIRMANIN METODOLOJISI}

\section{A. Araştırmanın Amacı, Önemi ve Literatüre Katkısı}

İletişim teknolojisinde yaşanan büyük gelişmenin akabinde insan hayatı bugüne dek hiç olmadığ kadar çok ve yine hiç olmadığ 1 kadar farklı şekillerde gözetlenmekte ve bu gözetim kayıt altına alınmaktadır. Söz konusu gözetimin bu denli fazla ve çeşitli olmasında en önemli etmen kuşkusuz internet ve internetin en önemli unsuru olan yeni medya ortamıdır. İnsanların hayatları bu yeni medya ortamındaki ağlar aracılığıyla kişilerin haberi olmadan gözetlenmekte ve manipüle edilmektedir. Bu ağların en popüleri ve gözetimin belki de en aleni yapıldığı mecra ise sosyal paylaşım ağlarıdır. Kişilerin haberi ve rızası olmadan gerçekleşen gözetim eylemleri aynı zamanda kişinin rızası ve gönüllü katılımıyla da gerçekleşebilmektedir.

$\mathrm{Bu}$ noktadan hareketle çalışmada, Türkiye'de yaşayan insanların sosyal paylaşım ağlarında bilgilerini ne oranda paylaştıklarını ve sosyal paylaşım ağları vasıtasıyla gözetlediklerin farkında olup olmadıklarını tespit etmek amaçlanmıştır. Yapılan bu çalışma, insanların yeni medya aracılığıyla nasıl gözetlendiğini ve insanların bu durum hakkında ne kadar bilinçli olduğunu ortaya çıkaracak olması hasebiyle önem arz etmektedir. 


\section{B. Araştırmanın Yöntemi, Evreni ve Örneklemi}

Türkiye'deki bireylerin sosyal paylaşım ağlarında gözetlendiklerinin farkında olup olmadıklarını tespit etmek adına saha araştırması yapılmış ve araştırmada anket tekniğinden yararlanılmıştır. Çalışma, Kasım 2015 ile Ocak 2016 tarihlerinde yapılmıştır.

Araştırmada evreni, Türkiye'deki 15 yaşın üzerindeki yaklaşık 36 milyon Facebook kullanıcısı oluşturmaktadır. Araştırmanın örneklemini ise, Türkiye'deki 12 bölgenin 26 alt bölgesinde ikamet eden, 15 yaşın üzerinde olan ve Facebook kullanan 5000 kişi oluşturmaktadır. Örneklem, ve Türkiye İstatistik Kurumu'nun ve Devlet Planlama Teşkilatı'nın oluşturduğu İstatistiki Bölge Birimleri Sınıflandırması baz alınarak belirlenmiş ve tabakalı örnekleme yöntemi kullanılmıştır.

Çalışmada güvenilirliği tespit etmek için veriler analiz edilmiş, analiz sonucunda Cronbach's Alpha değerinin 0,881 olduğu ve dolayısıyla anket verilerinin oldukça güvenilir olduğuna sonucuna varılmıştır. Veri analizinde Kuruskal-Wallis testi, Mann-Whitney U testi, Kolmogorov-Smirnov Testi ve Sıklık Analizinden yararlanılmıştır.

\section{Bulgular}

Katılımcılar ile ilgili demografik bilgiler incelendiğinde, kadın ve erkek oranının birbirine yakın olduğu, çoğunun 15-29 yaş aralı̆̆ında $(\% 75,5)$ bulunduğu, yarısından fazlasının $(\% 59,5)$ bir yükseköğretim kurumunda okumakta olduğu ya da mezun olduğu, çok büyük bir kısmının yaşamlarının büyük çoğunluğunu kentte geçirdiği $(\% 86,3)$, yine büyük bir kısmının öğrenci $(\% 59,4)$ olduğu ve $0-2000$ TL arasında gelir seviyesine $(\% 78,8)$ sahip olduğu görülmektedir (Tablo 1).

Tablo 1: Katılımcıların Demografik Özellikleri

\begin{tabular}{|l|l|l|l|}
\hline Demografik Özellikler & Kategoriler & Sayı & \% \\
\hline Cinsiyet & Kadın & 2564 & 51,3 \\
\cline { 2 - 4 } & Erkek & 2436 & 48,7 \\
\cline { 2 - 4 } & Toplam & $\mathbf{5 0 0 0}$ & $\mathbf{1 0 0 , 0}$ \\
\hline Yaş & $15-19$ & 1523 & 30,5 \\
\cline { 2 - 4 } & $20-24$ & 1441 & 28,8 \\
\cline { 2 - 4 } & $25-29$ & 809 & 16,2 \\
\cline { 2 - 4 } & $30-34$ & 519 & 10,4 \\
\cline { 2 - 4 } & $35-39$ & 272 & 5,4 \\
\cline { 2 - 4 } & $40+$ & 436 & 8,7 \\
\cline { 2 - 4 } & Toplam & $\mathbf{5 0 0 0}$ & $\mathbf{1 0 0 , 0}$ \\
\hline \multirow{5}{*}{ Eğitim } & Okur Yazar Değil & 29 & 0,6 \\
\cline { 2 - 4 } & Okur Yazar & 100 & 2,0 \\
\cline { 2 - 4 } & İlköğretim & 222 & 4,4 \\
\cline { 2 - 4 } & Lise & 1673 & 33,5 \\
\cline { 2 - 4 } & Üniversite & 2641 & 52,8 \\
\cline { 2 - 4 } & Yüksek Lisans-Doktora & 335 & 6,7 \\
\cline { 2 - 4 } & Toplam & $\mathbf{5 0 0 0}$ & $\mathbf{1 0 0 , 0}$ \\
\hline Yaşanılan Yer & Kent & 4316 & 86,3 \\
\cline { 2 - 4 } & Kır & 684 & 13,7 \\
\cline { 2 - 4 } & Toplam & $\mathbf{5 0 0 0}$ & $\mathbf{1 0 0 , 0}$ \\
\hline
\end{tabular}




\begin{tabular}{|l|l|l|l|}
\hline \multirow{4}{*}{ Meslek } & Öğrenci & 2968 & 59,4 \\
\cline { 2 - 4 } & Ücretli çalışan & 1284 & 25,7 \\
\cline { 2 - 4 } & Kendi hesabına çalışan - İşveren & 355 & 7,1 \\
\cline { 2 - 4 } & Diğer & 393 & 7,8 \\
\cline { 2 - 4 } & Toplam & $\mathbf{5 0 0 0}$ & $\mathbf{1 0 0 , 0}$ \\
\hline \multirow{5}{*}{ elir } & $500-1000 \mathrm{TL}$ & 2697 & 54,0 \\
\cline { 2 - 4 } & $1001-2000 \mathrm{TL}$ & 1244 & 24,8 \\
\cline { 2 - 4 } & $2001-3000 \mathrm{TL}$ & 559 & 11,2 \\
\cline { 2 - 4 } & $3001 \mathrm{TL}+$ & 500 & 10 \\
\cline { 2 - 4 } & Toplam & $\mathbf{5 0 0 0}$ & $\mathbf{1 0 0 , 0}$ \\
\hline
\end{tabular}

Çalışmada analizlerin düzenli bir tabloda sunulması ve farklı analizlerin yapılabilmesi amacıyla ilgili analizlerde katılımcıların demografik özelliklerinden "Yaş", "Çalışma Durumu" ve "Eğitim Durumu" ikili ve üçlü kategorilere indirgenmiştir. Yaş grubu, analizlerde kullanmak üzere iki kategoriye ayrılmıştır. Anket çalışmasına farklı mesleklere mensup kişilerin yanında öğrenciler ve bir işte çalışmayan kişiler de katılmıştır. Anket formunda 10 kategoriye ayrılmış olan meslekler, istatistiksel olarak anlamlı sonuçlara ulaşabilmek ve daha düzenli bir tablo oluşturabilmek adına üç kategoride toplanmıştır. Eğitim durumu ise, "İlköğretim ve Altı", "Lise" ve "Üniversite ve Üstü” olmak üzere üç kategoriye indirgenmiştir.

Katılımcıların internet ve Facebook kullanım bilgileri incelendiğinde, katılımcıların hemen hemen yarısının (\%51,9) interneti en fazla 3 saat kullandığ1, çok büyük bir kısmının $(\% 83,3)$ internete cep telefonu ile bağlandığı, yarısına yakınının $(\% 44,2)$ interneti en çok sosyal paylaşım ağlarına girmek için kullandığı, \%49,6'sının 3 veya üzeri sosyal paylaşım ağını kullandığı, hemen hemen yarısının $(\% 53,4)$ Facebook'u haftanın her günü kullandığı, yarısına yakınının $(\% 47,3)$ Facebook'u günde 1 saatten az kullandığı, Facebook'u en çok $(\% 33,8)$ arkadaşlarının paylaşımlarını takip etmek için kullandığı ve \%29,6'sının Facebook'ta 400'den fazla arkadaşa sahip olduğu görülmektedir (Tablo 2).

Tablo 2: Katılımc1ların İnternet ve Facebook Kullanımı

\begin{tabular}{|c|c|c|c|}
\hline & Kategoriler & Sayı & $\%$ \\
\hline \multirow[t]{5}{*}{ İnternet Kullanım Süresi } & 1 saatten az & 795 & 15,9 \\
\hline & $1-3$ saat & 1799 & 36,0 \\
\hline & 4-6 saat & 1325 & 26,5 \\
\hline & 7 saatten fazla & 1081 & 21,6 \\
\hline & Toplam & 5000 & 100,0 \\
\hline \multirow{3}{*}{$\begin{array}{l}\text { İnternete Cep } \\
\text { Telefonundan Bağlanma }\end{array}$} & Evet & 4164 & 83,3 \\
\hline & Hayır & 836 & 16,7 \\
\hline & Toplam & 5000 & 100,0 \\
\hline \multirow[t]{6}{*}{ İnternet Kullanım Amacı } & Sosyal paylaşım ağlarına girmek & 2214 & 44,2 \\
\hline & İnternette gezinmek & 1058 & 21,2 \\
\hline & Araştırma yapmak ve bilgi edinmek & 1018 & 20,4 \\
\hline & Oyun oynamak & 440 & 8,8 \\
\hline & Diğer & 270 & 5,4 \\
\hline & Toplam & 5000 & 100,0 \\
\hline \multirow{5}{*}{$\begin{array}{l}\text { Kullanılan Sosyal Paylaşım } \\
\text { Ağı Sayısı }\end{array}$} & 1 & 1182 & 23,6 \\
\hline & 2 & 1342 & 26,8 \\
\hline & 3 & 1037 & 20,7 \\
\hline & 4 veya üzeri & 1439 & 28,9 \\
\hline & Toplam & 5000 & 100,0 \\
\hline
\end{tabular}




\begin{tabular}{|c|c|c|c|}
\hline \multirow{6}{*}{$\begin{array}{l}\text { Haftalık Facebook } \\
\text { Kullanımı }\end{array}$} & 1 gün & 452 & 9,0 \\
\hline & 2-3 gün & 873 & 17,5 \\
\hline & 4 gün & 475 & 9,5 \\
\hline & $5-6$ gün & 532 & 10,6 \\
\hline & Her gün & 2668 & 53,4 \\
\hline & Toplam & 5000 & 100,0 \\
\hline \multirow{5}{*}{$\begin{array}{l}\text { Günlük Facebook } \\
\text { Kullanım Süresi }\end{array}$} & 1 saatten az & 2367 & 47,3 \\
\hline & 1-3 saat & 1688 & 33,8 \\
\hline & 4-6 saat & 591 & 11,8 \\
\hline & 7 saatten fazla & 354 & 7,1 \\
\hline & Toplam & 5000 & 100,0 \\
\hline \multirow[t]{6}{*}{ Facebook Kullanım Amacı } & Arkadaşların paylaşımlarını takip etmek & 1690 & 33,8 \\
\hline & Gündemi Takip etmek & 1404 & 28,1 \\
\hline & Arkadaşlarımla iletişim kurmak & 1105 & 22,1 \\
\hline & Fotoğraf, video ve yazı paylaşmak & 578 & 11,5 \\
\hline & Diğer & 223 & 4,5 \\
\hline & Toplam & 5000 & 100,0 \\
\hline \multirow{6}{*}{$\begin{array}{l}\text { Facebook'taki Arkadaş } \\
\text { Sayısı }\end{array}$} & 100'den az & 677 & 13,5 \\
\hline & 100-200 kişi & 1045 & 20,9 \\
\hline & 201-300 kişi & 995 & 19,9 \\
\hline & 301-400 kişi & 807 & 16,1 \\
\hline & 400'den fazla & 1476 & 29,6 \\
\hline & Toplam & 5000 & 100,0 \\
\hline
\end{tabular}

Çalışmaya dahil olan katılımcıların Facebook'taki gizlilik tutumları incelendiğinde ise, büyük bir kısmının Facebook profilinde gerçek adını $(\% 93,0)$, doğum tarihini $(\% 71,6)$, yaşadığı yeri $(\% 77,4)$, eğitim durumunu $(\% 66,5)$ ve memleketini $(\% 61,7)$ diğer kullanıcılarla paylaştığı görülmektedir. Bunun yanında katılımciların büyük bir kısmı $(\% 78,5)$ Facebook'a kayıt olurken kullanım şartlarını ve gizlilik politikalarını okumamıştır yahut okuyup okumadıklarını hatıllamamaktadır. Yine katılımcıların yarısına yakını $(\% 44,4)$ Facebook'taki gizlilik ayarlarını, büyük bir kısmı da $(\% 77,6)$ reklam ayarlarını yapmamıştır. Katılımcıların önemli bir kısmı da $(\% 41,0)$ zaman tünelini arkadaşlarının paylaşımına açmıştır (Tablo 3).

Tablo 3: Katılımcıların Facebook'taki Gizlilik Tutumları

\begin{tabular}{|l|l|l|l|}
\hline & Kategoriler & Sayı & \% \\
\hline \multirow{4}{*}{ Facebook Profilinde Yer } & Gerçek ad & 4632 & 93,0 \\
\cline { 2 - 4 } & Doğum tarihi & 3567 & 71,6 \\
\cline { 2 - 4 } & Yaşanılan yer & 3856 & 77,4 \\
\cline { 2 - 4 } & Eğitim durumu & 3311 & 66,5 \\
\cline { 2 - 4 } & Illişki durumu & 1444 & 29,0 \\
\cline { 2 - 4 } & Yapılan iş & 1963 & 39,4 \\
\cline { 2 - 4 } & Memleket & 3072 & 61,7 \\
\cline { 2 - 4 } & Aile veya akrabalar & 1153 & 23,2 \\
\hline \multirow{5}{*}{$\begin{array}{l}\text { Sacebook'un Kullanım } \\
\text { Politikasını Gizlilik }\end{array}$} & Evet & 1075 & 21,5 \\
\cline { 2 - 4 } & Hayır & 2526 & 50,5 \\
\cline { 2 - 4 } & Hatırlamıorum & 1399 & 28,0 \\
\cline { 2 - 4 } & Toplam & $\mathbf{5 0 0 0}$ & $\mathbf{1 0 0 , 0}$ \\
\hline Facebook'ta Gizlilik & Evet & 2778 & 55,6 \\
\cline { 2 - 4 } Ayarlarını Yapma & Hayır & 2222 & 44,4 \\
\cline { 2 - 4 } & Toplam & $\mathbf{5 0 0 0}$ & $\mathbf{1 0 0 , 0}$ \\
\hline
\end{tabular}




\begin{tabular}{|l|l|l|l|}
\hline \multirow{2}{*}{$\begin{array}{l}\text { Facebook'ta Reklam } \\
\text { Kisitlamasını Yapma }\end{array}$} & Evet & 1121 & 22,4 \\
\cline { 2 - 4 } & Hayır & 3879 & 77,6 \\
\cline { 2 - 4 } & Toplam & $\mathbf{5 0 0 0}$ & $\mathbf{1 0 0 , 0}$ \\
\hline \multirow{2}{*}{$\begin{array}{l}\text { Facebook'ta Etiketlenince } \\
\text { Direkt Zaman Tünelinde } \\
\text { Görülme }\end{array}$} & Evet & 2049 & 41,0 \\
\cline { 2 - 4 } & Hayır & 2951 & 59,0 \\
\cline { 2 - 4 } & Toplam & $\mathbf{5 0 0 0}$ & $\mathbf{1 0 0 , 0}$ \\
\hline
\end{tabular}

Çalışmada ayrıca katılımcıların Facebook aracılığıyla gözetlendiklerinin ne oranda farkında oldukları incelenmiştir. Katılımcıların Facebook'taki kişisel bilgilerine onlar istemedikçe kimsenin ulaşamayacağını düşünme konusunda aldıkları ortalama puan "62,4”, Facebook'ta gizlilik ayarlarını yaptıkları zaman arkadaşlarının haricinde kimsenin onları izleyemeyeceğini düşünme puanı "64,5", kanuna aykırı bir şey yapmadıkça kamu kuruluşları tarafindan Facebook aracılığıyla gözetlenmeyeceklerini düşünme puanı “62,4”, Facebook'taki bilgilerinin onların haberi olmadan kamu kuruluşları ve şirketler tarafından ele geçirilip depolanamayacağını düşünme puanı " 55,5 " ve ticari şirketlerin Facebook’taki bilgilerine onların izni olmadan ulaşamayacağını düşünme puanı da " 56,8 " olmaktadir (Tablo 4).

Tablo 4: Facebook’ta Gözetimin Farkındalığ1

\begin{tabular}{|c|c|c|c|c|c|c|c|}
\hline Gözetimin Farkındalığı & 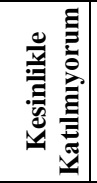 & E & 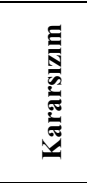 & 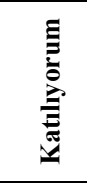 & 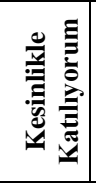 & 菢 & 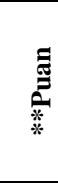 \\
\hline $\begin{array}{l}\text { Facebook'taki kişisel bilgilerime ben istemedikçe } \\
\text { kimsenin ulaşamayacağını düşünüyorum. }\end{array}$ & $\% 15,7$ & $\% 18,9$ & $\% 21,4$ & $\% 25,8$ & $\% 18,2$ & 3,1 & 62,4 \\
\hline $\begin{array}{l}\text { Facebook’ta gizlilik ayarlarını yaptığım zaman } \\
\text { arkadaşlarımın haricinde kimsenin beni } \\
\text { izleyemeyeceğini düşünüyorum. }\end{array}$ & $\% 14,0$ & $\% 16,6$ & $\% 21,0$ & $\% 29,4$ & $\% 19,0$ & 3,2 & 64,5 \\
\hline $\begin{array}{l}\text { Kanuna aykırı bir şey yapmadıkça kamu kuruluşları } \\
\text { tarafindan Facebook aracılığıyla gözetlenmeyeceğimi } \\
\text { düşünüyorum. }\end{array}$ & $\% 17,4$ & $\% 15,3$ & $\% 23,1$ & $\% 25,9$ & $\% 18,3$ & 3,1 & 62,4 \\
\hline $\begin{array}{l}\text { Facebook'taki bilgilerimin benim haberim olmadan } \\
\text { kamu kuruluşları ve şirketler tarafından ele geçirilip } \\
\text { depolanamayacağını düşünüyorum. }\end{array}$ & $\% 23,5$ & $\% 19,0$ & $\% 26,4$ & $\% 18,6$ & $\% 12,5$ & 2,8 & 55,5 \\
\hline $\begin{array}{l}\text { Ticari şirketlerin Facebook'taki bilgilerime benim } \\
\text { iznim olmadan ulaşamayacağını düşünüyorum. }\end{array}$ & $\% 21,1$ & $\% 19,6$ & $\% 24,0$ & $\% 24,5$ & $\% 10,8$ & 2,8 & 56,8 \\
\hline \multicolumn{6}{|l|}{ Ortalama } & 3,0 & 60,3 \\
\hline
\end{tabular}

* 5'lik Sistem

** 100'lük Sistem

Katılımcıların Facebook aracığıyla gözetlendiklerinin farkında olup olmadıklarının cinsiyetlerine göre bir farklılık arz edip etmediğine bakıldığında, Mann-Whitney $U$ testi ile elde edilen sonuca göre, cinsiyet ile gözetimin farkındalığı arasında \%5 anlamlılık düzeyinde (p. 0,00) bir ilişkinin söz konusu olduğu görülmektedir. Kadınlar gözetlendiklerinin farkında olmama noktasında ise 62,3 puan almışken erkekler 58,3 puan almıştır (Tablo 5).

Tablo 5: Gözetimin Farkındalığının Cinsiyete Göre Grupsal Karşılaştırması

\begin{tabular}{|l|l|}
\hline & \multicolumn{1}{|c|}{ Gözetim } \\
\hline Mann Whitney U & 2782288,500 \\
\hline Wilcoxon W & 5750554,500 \\
\hline Z & $-6,688$ \\
\hline Asymp. Sig. (2-tailed) & $\mathbf{0 0 0}$ \\
\hline
\end{tabular}

\begin{tabular}{|l|l|l|}
\hline \multirow{2}{*}{} & \multicolumn{2}{|c|}{ Cinsiyet } \\
\cline { 2 - 3 } Gözetim & Kadın (Puan) & Erkek (Puan) \\
\hline & 62,3 & 58,3 \\
\hline
\end{tabular}


Katılımcıların Facebook aracığıyla gözetlendiklerinin farkında olup olmadıklarının yaşlarına göre bir farklılık gösterip göstermediğine bakıldığında, Mann-Whitney U testi ile elde edilen sonuca göre, yaş ile gözetimin farkındalığ arasında da \%5 anlamlılık düzeyinde (p. 0,00) bir ilişki söz konusudur. Dijital yerliler gözetlendiklerinin farkında olmama noktasında 65,2 puan almışken dijital göçmenler 53,3 puan almıştır (Tablo 6).

Tablo 6: Gözetimin Farkındalığının Yaşa Göre Grupsal Karşılaştırması

\begin{tabular}{|c|c|c|c|c|}
\hline & Gözetim & & \multicolumn{2}{|c|}{ Yaş } \\
\hline & & & \multirow{3}{*}{$\begin{array}{l}\text { Dijital } \\
\text { Yerliler } \\
\text { (Puan) }\end{array}$} & \multirow{3}{*}{$\begin{array}{c}\text { Dijital } \\
\text { Göçmenleı } \\
\text { (Puan) }\end{array}$} \\
\hline Mann Whitney U & 2060332,500 & & & \\
\hline Wilcoxon W & 4133998,500 & & & \\
\hline $\mathrm{Z}$ & $-19,115$ & \multirow{2}{*}{ Gözetim } & \multirow{2}{*}{65,2} & \multirow{2}{*}{53,3} \\
\hline Asymp. Sig. (2-tailed) & ,000 & & & \\
\hline
\end{tabular}

Katılımcıların Facebook aracığıyla gözetlendiklerinin farkında olup olmadıklarının eğitim durumlarına, mesleklerine ve yaşadıkları bölgeye göre bir farklılık arz edip etmediğine bakıldığında ise, Kruskal-Wallis testi ile elde edilen sonuca göre, eğitim durumu, meslek ve yaşanılan bölge ile gözetimin farkındalığ arasında \%5 anlamlılık düzeyinde (p. 0,00) bir ilişki söz konusudur. Gözetlendiklerinin farkında olmama noktasında ilköğretim ve altı grubundakiler 65,7 lise grubundakiler de 66,4 puan almışken üniversite ve üstü grubundakiler 56,3 puan almıştır. Mesleğe göre de öğrenciler 63,8 puan almışken çalışanlar 54,0 puan almıştır. Bölgeye göre ise, Karadeniz Bölgesi'ndekiler 61,9 puan almışken Ege Bölgesi'ndekiler 57,7 puan almıştır (Tablo 7).

Tablo 7: Eğitim, Meslek ve Bölgeye Göre Gözetimin Farkındalığı

\begin{tabular}{|l|l|l|}
\hline & \multicolumn{1}{|c|}{ Gözetimin Farkndalı̆̆ } & \multicolumn{1}{|c|}{ Puan } \\
\hline \multirow{4}{*}{ Ĕgitim Durumu } & İlköğretim ve altı & 65,7 \\
\cline { 2 - 3 } & Lise & 66,4 \\
\cline { 2 - 3 } & Üniversite ve üstü & 56,3 \\
\hline \multirow{4}{*}{ Meslek } & Çalışan & 54,0 \\
\cline { 2 - 3 } & Öğrenci & 63,8 \\
\cline { 2 - 3 } & İşsiz & 62,2 \\
\hline \multirow{5}{*}{ Yaşanılan Bölge } & Akdeniz & 60,6 \\
\cline { 2 - 3 } & Doğu Anadolu & 58,9 \\
\cline { 2 - 3 } & Ege & 57,7 \\
\cline { 2 - 3 } & Güneydoğu Anadolu & 61,7 \\
\cline { 2 - 3 } & İç Anadolu & 60,0 \\
\cline { 2 - 3 } & Karadeniz & 61,9 \\
\cline { 2 - 3 } & Marmara & 61,0 \\
\hline
\end{tabular}

SONUÇ

Hem ticari şirketler hem de gücü elinde bulunduran erkler, varlıklarını devam ettirmek, daha fazla güç elde etmek ya da maddi çıkar sağlamak adına halkı sistematik biçimde gözetlemekte, onların kişisel bilgilerini depolamakta ve insanların özel alanlarını birçok farklı şekilde ihlal etmektedir. Özellikle de internet teknolojisinin getirmiş olduğu imkanlarla insanların sosyal ağlardaki hesapları, kimlik bilgileri, özel ve genel yazışmaları, fotoğrafları ve daha bir çok kişisel bilgisi onların izni ve haberi olmadan ele geçirilmekte, kullanılmakta ya da kullanılmak üzere veri depolarında saklanmaktadır. Gerçekleştirilen tüm bu 
gözetim faaliyetlerinin kuşkusuz en yoğun gerçekleştirildiği mecra ise sosyal paylaşım ağlarıdır.

$\mathrm{Bu}$ noktadan hareketle yapılan çalışmada, bireylerin kişisel bilgilerini sanal ağda ne oranda paylaştıkları ve gözetlendiklerinin ne oranda farkında oldukları tespit edilmeye çalışılmıştır. Çalışmada, farklı yaşlarda olan, farklı eğitim seviyelerine sahip ve farklı mesleklere mensup olan katılımcıların, interneti ve Facebook'u ne düzeyde kullandıkları incelendiğinde, yaklaşık yarısının günde en az 4 saatini internete ayırdığını, çok büyük bir kısmının internete cep telefonu aracılığıyla bağlandığı, interneti en çok sosyal paylaşım ağlarına girmek için kullandığ 1 ve hemen hemen yarısının en az 3 tane sosyal paylaşım ağını aktif olarak kullandığı görülmektedir. İnterneti bu yoğunlukta kullanan katılımcılar Facebook'u da aynı oranda kullanmaktadır. Katılımcıların yarısından fazlası Facebook'a her gün girmekte ve yine yarısından fazlası günde en az 1 saat Facebook'u kullanmaktadır. Zhao'nun (2012: 37) sosyal paylaşım ağları ile ilgili yapmış olduğu araştırmada da katılımcıların yarısından fazlası Facebook'a her gün girmekte ve yarısına yakını Facebook'u günde en az 1 saat kullanmaktadır. Facebook'u kullanan bireyler Facebook'u en çok arkadaşlarının paylaşımını takip etmek sonrasında da en çok gündemi takip etmek için kullanmaktadır. Katılımcıların yarısına yakınının ise bu sosyal paylaşım ağında en az 300 arkadaşa sahip olmaktadır.

Çalışmada katılımcıların büyük çoğunluğu profillerinde, memleket, eğitim durumu, yaşanılan yer, doğum tarihi ve gerçek ad gibi kişisel bilgileri kullanmaktadır. Bunun yanında katılımcıların yarısından azı da, akrabalar, aile, iş durumu ve ilişki durumu gibi özel bilgileri profillerinde paylaşmaktadır. Bulgular, Dillard'ın (2011: 95-97), Afsahi'nin (2014: 44) ve Zhang'ın (2014: 36), insanların çoğunun kişisel bilgilerini (doğum tarihi, gerçek ad, eğitim durumu, yaşanılan yer) Facebook profillerinde paylaştıklarını ortaya koyduğu çalışmalarla benzerlik içindedir. Kişisel bilgilerini bu denli insanların, şirketlerin ve kamu kuruluşlarının gözetimine sunan kullanıcılar, bilgilerinin görece güvenli saklanması için Facebook üzerinden gerekli işlemleri de (kullanım koşulları, gizlilik anlaşması, gizlilik ayarları, reklam kısıtlaması, zaman tüneli ayarlaması vb.) büyük oranda gerçekleştirmemektedirler.

Katılımcıların Facebook aracılığıyla, kamu kurumları ve ticari şirketler tarafından gözetlendiğinin farkında olup olmadıkları incelendiğinde ise, yarısına yakınının Facebook'taki kişisel bilgilerine onlar istemedikçe hiç kimsenin erişemeyeceğini ve Facebook'un ayarlar sekmesinde yer alan gizlilik ayarı yapıldığında Facebook'taki arkadaşlardan hariç başka hiç kimsenin kendilerini izleyeme imkanını bulamayacağını düşündükleri görülmektedir. Bunun yanında, yine katılımcıların yarısına yakını kanunlara aykırı bir davranışta bulunmadıkları sürece kamu kurumları tarafından Facebook aracılığıyla gözetlenmeyeceklerini düşünmektedir. Hemen hemen her 3 katılımcidan birisi de, kendileri izin vermeden ve haberleri olmadan kamu kurumlarının ve ticari şirketlerin Facebook'taki kişisel bilgilerine ulaşamayacağını ve bu bilgileri depolayamayacağını düşünmektedir. Özetle, katılımcıların çoğu Facebook 
aracılığıyla kamu kurumları ve ticari şirketler tarafından izlendiklerinin tam olarak farkında olmamaktadırlar. Ancak katılımcılar kamu kurumları tarafından yapılan gözetimden ziyade ticari şirketler tarafindan yapılan gözetimin daha fazla farkında olmaktadırlar. Uzkurt ve Torlak'ın (2005: 24) bireylerin mahremiyet algılarını ölçme amacıyla yaptıkları çalışmada da aynı sonuca ulaşılmıştır. Çalışmada bireylerin, kendilerine ait mahrem bilgilerin ticari şirketler tarafindan ele geçirilip kullanıldığının farkındalığı yüksektir. Ancak genel çerçeveden bakıldığında Dillard ve (2011: 103), Hoy ve Milne (2010: 36) de yaptıklar1 çalışmalarda aynı sonuca ulaşmışlardır. Çalışmalarda görüldüğü gibi bireyler çoğunlukla gözetlemelerin farkında tam anlamıyla olmamaktadırlar. Daha da önemlisi bireyler, gözetimin hangi boyutlarda yapıldığının, nasıl gerçekleştiğinin ve kişisel bilgilerin ne kadar korunabilir olduğunun bilincinde olmamaktadır.

Bunun yanında gözetim farkındalığ 1 ĕgitim, yaş, cinsiyet, meslek ve ikamet edilen bölgeye göre farklılık arz etmektedir. Erkekler kadınlara nazaran kamu kurumları ve ticari şirketlerce gözetlendiklerinin daha çok farkındadırlar. Aynı şekilde bu bireylerin yaşları arttıkça gözetim farkındalığı da artmaktadır. Öyle ki, verilere göre dijital göçmenler dijital yerlilere göre gözetlendiklerinin daha fazla farkında olmaktadır. Eğitim açısından gözetim farkındalığına bakıldığında ise, üniversite ve üzeri eğitime sahip olanlar daha az eğitime sahip olanlara göre gözetimin daha fazla farkında olmaktadırlar. Meslek noktasında ise çalışan bireyler, işsizlere ve öğrencilere göre gözetimin daha fazla farkında olmaktadır. Gözetim farkındalığına yaşanılan bölge bazında bakıldığında ise, Ege bölgesindeki bireyler gözetim farkındalığı en fazla olan bölge iken Karadeniz bölgesi gözetim farkındalığının en düşük olduğu bölgedir.

\section{KAYNAKÇA}

Afsahi, A. (2014). Social Networking Dilemmas for Psychologists: Privacy, Professionalism, Boundary Issues, and Policies. Antioch University, Psychology, Doctorate Thesis, America.

Ak, H. (2013). Büyük Birader ve Gözetim Devleti. M. Balcı (Ed.). Genç Hukukçular Hukuk Okumaları Birikimler 4 (s. 381-389). İstanbul: Fakülteler Matbaası.

Assange, J., Appelbaum, J., Maguhn, A. M. \& Zimmermann, J. (2013). Şifrepunk 'Özgürlük ve Internetin Geleceği Üzerine Bir Tartı̧ma'. İstanbul: Metis Yayınları.

Bauman, Z. (2012). Küreselleşme - Toplumsal Sonuçları. İstanbul: Ayrıntı Yayınları.

Bauman, Z. \& Lyon, D. (2013). Akışkan Gözetim. İstanbul: Ayrıntı yayınları.

Bentham, J. (2008). Panoptikon ya da Gözetim-Evi. B. Çoban - Z. Özarslan (Ed.). Panoptikon: Gözün İktidarl (s. 9-75). İstanbul: Su Yayınları.

Dillard, T. E. (2011). Privacy and Security İmplications of Undergraduate Students Using Facebook: A Quantitative Examination. Capella University, Philosophy, Doctorate Thesis, America.

Dinev, T., Hart, P. \& Mullen, M. R. (2008). Internet Privacy Concerns and Beliefs about Government Surveillance - An Empirical İnvestigation. Journal of Strategic Information Systems, 17, 214-233.

Dolgun, U. (2005a). İste Büyük Birader. İstanbul: Hayykitap.

Dolgun, U. (2008). Şeffaf Hapishane Yahut Gözetim Toplumu: Küreselleşen Dünyada Gözetim, Toplumsal Denetim ve İktidar Illişkileri. Ankara: Ötüken Neşriyat.

Erdal, C. (2013). Sosyal Medya ve 'Paylaşım Kültürü'. C. Bilgili ve G. Şener (Ed.). Sosyal Medya ve Ağ Toplumu-2: Kültür, Kimlik, Siyaset (s. 55-65). İstanbul: Grafik Tasarım Yayıncılık.

Foucault, M. (1992). Hapishanenin Doğuşu. Ankara: İmge Kitabevi Yayınları. 
Fuchs, C. (2012). Implications of Deep Packet Inspection (DPI) Internet Surveillance for Society. The Privacy \& Security Research Paper Series.

Giddens, A. (2008). Ulus Devlet ve Şiddet. İstanbul: Kalkedon Yayınları.

Güven, S. K. (2011). Gözetimin Toplumsal Meşruiyeti. H. Köse (Ed.). Medya Mahrem: Medyada Mahremiyet Olgusu ve Transparan Bir Yaşamdan Parçalar (s. 173-198). İstanbul: Ayrıntı Yayınları.

Hoy, M. G. \& Milne, G. (2010). Gender Differences in Privacy Related Measures for Young Adult Facebook Users. Journal of Interactive Advertising, 10 (2), 28-45.

Karakehya, H. (2009). Gözetim ve Suçla Mücadele: Gözetimin Tarihsel Gelişimi ile Yakın Dönemde Gerçekleştirilen Hukuki Düzenleme ve Uygulamalar Bağlamında Bir Değerlendirme. Ankara Üniversitesi Hukuk Fakültesi Dergisi, 58, 319-357.

Köse, H. (2011). Medya Mahrem: Medyada Mahremiyet Olgusu ve Transparan Bir Yaşamdan Parçalar. İstanbul: Ayrıntı Yayınları.

Lyon, D. (2013). Gözetim Çalışmaları. İstanbul: Kalkedon Yayınları.

Marx, G. T. (1985). The Surveillance Society: The Threat of 1984-style Techniques. The Futurist, 6, 6-21.

Özarslan, Z. (2008). Gözün İktidarı: Elektronik Gözetim Sistemleri. B. Çoban ve Z. Özarslan (Ed.). Panoptikon: Gözün İktidarı (s.139-153). İstanbul: Su Yayınları.

Rosen, J. (2004). The Naked Crowd Reclaiming Security and Freedom in an Anxious Age. USA: Random House.

Saykozof (2014). Birbirini Pekiştiren Kavramlar: Panoptikon ve Sinoptikon http://saykozof.blogspot.com.tr/2014/06/birbirini-pekistiren-kavramlar.html, $\quad$ Erişim Tarihi: 05.10.2.15.

Stalder, F. (2002). Opinion. Privacy is not the Antidote to Surveillance. Surveillance \& Society, 1, 1, $120-124$.

Toktaş, S. A., Binark, M., Dikmen, E. Ş., Fidaner, I. B., Küzeci, E. \& Özaygen, A. (2012). Türkiye'de Dijital Gözetim T.C. Kimlik Numarasından E-Kimlik Kartlarına Yurttaşın Sayısal Bedenlenişi. İstanbul: Alternatif Bilişim Derneği Yayınevi.

Toprak, A., Yıldırım, A., Aygül, E., Binark, M., Börekçi, S. \& Çomu, T. (2009). Toplumsal Paylaşım Ağl Facebook: "görülüyorum öyleyse varım!’. İstanbul: Kalkedon Yayınları.

Tümurtürkan, M. (2010). Gündelik Hayatın Gözetimi: "Panoptikon Toplumu”. ETHOS: Felsefe ve Toplumsal Bilimlerde Diyaloglar, 3 (2), 1-19.

Uzkurt, C., Torlak, Ö. (2005). Müşteri Mahremiyeti ve Müşterilerin Mahremiyet İlgisini Ölçmeye Yönelik Bir Uygulama. Yönetim, 51, 13-24.

Westin, A. F. (1967). Privacy and Freedom. New York: Atheneum.

Zhang, Y. (2014). A Cross-Site Study of User Behavior And Privacy Perception in Social Networks. Purdue University, Science, Master Thesis, America.

Zhao, X. (2012). Why We Disclose Differently: How Social Networking Site Affordances Affect Privacy Concerns And Disclosure Practices in Cross-Cultural Contexts. Purdue University, Arts, Master Thesis, America.

\section{SUMMARY}

The phenomenon of surveillance has always existed as a form of control in the history of mankind. People have been observed in different ways and different types by individuals that have the power. However, along with the modern period, surveillance practices have also changed. Now, the surveillance of the individual and the society has become much more comprehensive and electronic. These surveillance activities and tools have reached the level to be able to follow the whole humanity in the modern period and have made mass surveillance much easier.

Besides, right to protection of personal information and private life, which is an indispensable part of human rights, is violated different ways and 
numerous with technological developments and new communication tools are integrated human life. Especially when considering the prevalence and domain, Internet is the most imprtant media pave the way fort his violation in this mass communication. This virtual environment that eliminates concept of time and space and puts the world into a small computer screen or smart phone, gave the promise unlimited freedom to individual. Individual also, is deceived by freedom illusion and he transfer his informations in this virtual environment without query. Individual has led to surveillance his home address, telephone number, family, identity information, private moments, inside of home and bedroom to other individuals, goverment and commercial companies. individuals that have the power undertake mass surveillance to control society and gain political power. Commercial companies are mainly observing the masses in order to gain more financial gain.

Technological opportunities that have brought the dijimodern era, deterioration in the social structure, goverment and commercial companies spy society and being and watch of people have caused transformation and loss of control over the sphere of life.

This study aims to determine both how much the Turkish people share their knowledge in the new media and whether Turkish people are aware that they are being monitored through the new media. So a field study was conducted to obtain data in November 2015- January 2016. Survey technique which one of the quantitative research methods was used in this study. Population of survey's study is 53 million people ( 30 millon Facebook users) aged 15 and over in living Turkey. Sample of study is 5000 Facebook users aged 15 and over which are selected by stratified sample method. In the part of analysis of study was found participants share at what rate private information and they was aware of surveillance at what rate by goverments and commertial companies. Furthermore, It was copmared surveillance awareness and demographic characteristics of the participants on the basis of different variables and It was came up with significant differences.

According to the findings of the study, the level of sharing the information of the participants in Facebook is high. Furthermore, the level of awareness of participants being watched by commercial companies and public institutions through Facebook is low. The surveillance awareness of participants were also analyzed on the basis of gender, age, education, place of residence, working status and region groups, and significant differences were found. 